\title{
Latino Students Patient Safety Questionnaire: cross-cultural adaptation for Brazilian nursing and medical students
}

\author{
Latino Students Patient Safety Questionnaire: adaptação transcultural para estudantes \\ brasileiros de enfermagem e de medicina \\ Latino Students Patient Safety Questionnaire: adaptación transcultural para estudiantes \\ brasileños de enfermería y de medicina
}

\begin{abstract}
Aline Carrilho Menezes'
ORCID: 0000-0001-7658-4039

Carolina de Sousa Penha'

ORCID: 0000-0003-1110-8095
\end{abstract}

Fabrícia Moreira Amorim Amaral' ORCID: 0000-0003-4765-0062

Adriano Marçal Pimenta" ORCID: 0000-0001-7049-7575

Helen Cristiny Teodoro Couto Ribeiro ORCID: 0000-0001-9365-7228

Adriana Silvina Pagano" ORCID: 0000-0002-3150-3503

Luciana Regina Ferreira da Mata' ORCID: 0000-0002-5080-4643

'Universidade Federal de São João del-Rei. Divinópolis, Minas Gerais, Brazil.

"Universidade Federal de Minas Gerais. Belo Horizonte, Minas Gerais, Brazil.

How to cite this article: Menezes AC, Penha CS, Amaral FMA, Pimenta AM, Ribeiro HCTC, Pagano AS, et al. Latino Students Patient Safety Questionnaire: cross-cultural adaptation for Brazilian nursing and medical students.

Rev Bras Enferm. 2020;73(Suppl 6):e20190621. doi: http://dx.doi.org/10.1590/0034-7167-2019-0621

Corresponding author: Luciana Regina Ferreira da Mata E-mail: lucianarfmata@gmail.com

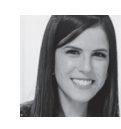

EDITOR IN CHIEF: Antonio José de Almeida Filho ASSOCIATE EDITOR: Rafael Silva

Submission: 12-09-2019

Approval: 06-10-2020

\begin{abstract}
Objectives: to perform a cross-cultural adaptation of the Latino Student Patient Safety Questionnaire for Brazilian Nursing and Medical students. Methods: methodological study carried out in six stages - forward translation, synthesis, back-translation, expert committee assessment, pre-test and reporting to the authors of the original instrument. Data at the expert committee and pre-test stages were collected and analyzed using the web platform e-Surv. The level of agreement adopted for the expert committee evaluation with 20 participants and the pre-test evaluation with 38 students was $\geq 90 \%$. Results: the first evaluation round by the expert committee showed a $<90 \%$ agreement for 21 out of the 26 questionnaire items, requiring adjustments. In the pre-test, three items in the instrument reached a $<90 \%$ agreement and were revised to obtain the final version. Conclusions: the Brazilian version of the Latino Student Patient Safety Questionnaire instrument was considered culturally adapted to Brazilian Portuguese.

Descriptors: Patient Safety; Validation Study; Cross-Cultural Comparison; Students, Nursing; Students, Medical.
\end{abstract}

\section{RESUMO}

Objetivos: realizar a adaptação transcultural do Latino Students Patient Safety Questionnaire para estudantes brasileiros de Enfermagem e de Medicina. Métodos: estudo metodológico realizado em seis etapas - tradução, síntese das traduções, retrotradução, comitê de especialistas, pré-teste e apresentação dos relatórios para os autores do instrumento original. Os dados das etapas "comitê de especialistas" e "pré-teste" foram coletados e analisados por meio da plataforma web e-Surv. O nível de concordância adotado entre as respostas do comitê formado por 20 especialistas e dos 38 estudantes no pré-teste foi de $\geq 90 \%$. Resultados: na primeira rodada de avaliação pelo comitê de especialistas, 21 dos 26 itens do questionário apresentaram concordância $<90 \%$, necessitando de ajustes. No pré-teste, três afirmativas do instrumento tiveram concordância $<90 \%$ e, portanto, foram readequadas para formulação da versão final. Conclusões: a versão brasileira do instrumento Latino Students Patient Safety Questionnaire foi considerada adaptada culturalmente para o português brasileiro.

Descritores: Segurança do Paciente; Estudos de Validação; Comparação Transcultural; Estudantes de Enfermagem; Estudantes de Medicina.

\section{RESUMEN}

Objetivos: realizar la adaptación transcultural del Latino Students Patient Safety Questionnaire para estudiantes brasileños de enfermería y de medicina. Métodos: estudio metodológico realizado en seis etapas — traducción, síntesis de las traducciones, retrotraducción, comité de especialistas, pre-prueba y presentación de los informes para los autores del instrumento original. Los datos de las etapas "comité de especialistas" y pre-prueba se recogieron y analizaron por medio de la plataforma web e-Surv. El nivel de concordancia adoptado para evaluar las respuestas del comité formado por 20 especialistas y de los 38 estudiantes en el pre- prueba fue de $\geq 90 \%$. Resultados: en la primera rodada de evaluación por el comité de especialistas, 21 de los 26 ítems del cuestionario presentaron concordancia < $90 \%$, necesitando de ajustes. En el pre-prueba, tres afirmativas del instrumento tuvieron concordancia $<90 \%$ y, fueron reformuladas en la versión final. Conclusiones: la versión brasileña del instrumento Latino Students Patient Safety Questionnaire ha sido considerada adaptada culturalmente para el portugués brasileño.

Descriptores: Seguridad del Paciente; Estudios de Validación; Comparación Transcultural; Estudiantes de Enfermería; Estudiantes de Medicina. 


\section{INTRODUCTION}

Addressing "patient safety" in the curricula of undergraduate courses in healthcare sciences is critical towards developing a non-punitive culture bearing in mind that students are prospective health professionals $s^{(1)}$. In this context, in 2011 the World Health Organization (WHO) published the Multi-professional Patient Safety Curriculum Guide, with guidelines to teachers on how to build knowledge related to the topic ${ }^{(2)}$. In Brazil, the National Patient Safety Program (PNSP) also establishes patient safety to be part of education and training as a cross-sectional axis of the teaching-learning process ${ }^{(3)}$.

In high income countries, undergraduate courses in Nursing and Medicine have already provided for patient safety inclusion ${ }^{(4)}$. In contrast, low and mid-income countries face major problems, such as poor educational infrastructures, scarce financial and human resources, difficulty to integrate patient safety and the local context, lack of knowledge regarding leadership in the healthcare field and scarce teacher engagement and cooperation ${ }^{(4-5)}$.

Research in Brazil has pointed out that healthcare errors and complications are topics neglected in Nursing and Medicine courses in the country $y^{(6-11)}$. Students report the need for education and training in communication, risk assessment, accountability and the inevitability of human failure ${ }^{(6,9-11)}$. Patient safety in Brazil is still sparse throughout the curriculum and there is no approach recruiting different disciplinary fields and integrating theory and clinical practice ${ }^{(7,10-11)}$.

In order to identify content gaps and guide the development of new skills in academic curricula, it is relevant to assess knowledge about patient safety during training ${ }^{(6,9-10,12)}$. Within this perspective, the Latino Students Patient Safety Questionnaire (LSPSQ) was developed in 2015 and validated in the context of Spanish-speaking Latin American countries. The instrument targets nursing and medical students and seeks to assess their knowledge and attitudes about patient safety in hospital practical activities ${ }^{(5)}$.

No valid instruments have been found for the above purpose in Brazil. Among the international instruments of quantitative approach that have gone through the validation process( ${ }^{(5,13-16)}$, the LSPSQ $^{(5)}$ is particularly suitable as it was developed for societies bearing some resemblance to the Brazilian culture and considers attitude assessment an essential construct in the analysis of the academic education process. Cross-culturally adapting the LSPSQ to be applied to Brazilian students is hence a methodological.

Although patient safety is relevant to several courses in the healthcare sciences, our study targeted nursing and medicine students, as the LSPSQ was originally developed and validated with these two courses as targets. Student assessment through this instrument is expected to inform course coordinators, teachers and administrators at educational institutions as to which competences regarding patient safety need to be part of medical and nursing training in Brazil.

\section{OBJECTIVES}

To perform a cross-cultural adaptation the LSPSQ for Brazilian nursing and medical students.

\section{METHODS}

\section{Ethical aspects}

The study was approved by the Research Ethics Committee at Universidade Federal de São João del-Rei (UFSJ) under Certificate of Presentation for Ethical Appreciation (CAAE) No. 1,785,522/16. Following Resolution 466/12 of the National Health Council, the participants signed a Free and Informed Consent Form (TCLE).

\section{Design, period and place of study}

This is a methodological study ${ }^{(17-19)}$ with authorization by the authors of the original version was sought prior to study execution, and was carried out from March 2016 to October 2017, at Universidade Federal de São João del-Rei (UFSJ). The study was developed as a master's thesis.

\section{Population: criteria of inclusion and exclusion}

The expert committee was composed of 20 professionals ( 10 healthcare professionals and 10 linguists trained in translation). The number of participants at this stage was defined based on the adopted methodological framework, which recommends from 6 to 20 specialists ${ }^{(20)}$. For all professionals, two inclusion criteria were considered: prior experience in expert committee participation translation and cross-cultural adaptation and proficiency in Spanish. To recruit healthcare professionals, patient safety was also a criterion implemented based on meeting one or more of the following criteria: having published or pursued graduate studies (diploma, master's or doctoral degrees) on the topic; being a lecturer or having taught courses on the subject; and having been a member of a patient safety unit in a healthcare institution. Recruitment was done by convenience, candidates named by researchers who have engaged in translation and cross-cultural adaptation of healthcare instruments. An email was sent to each expert with an invitation letter, a link to access the e-Surv web platform, a consent form.

Drawing on our methodological framework, which recommends 30 to 40 participants for the pre-test stage ${ }^{(17)}, 62$ undergraduate students in nursing and medicine were sent invitations, out of which 38 replied, 19 students affiliated to each course. The following selection criteria were considered: senior Nursing students (8th and 9th course semesters), senior Medical students (9th, 10th, 11 th and 12th course semesters), being engaged in supervised internships and having prior experience in hospital practice ${ }^{(5,21)}$. An invitation letter was sent by e-mail together with a link to access the e-Surv web platform and a consent form appended to it.

\section{Study protocol}

The LSPSQ is a self-administered questionnaire, with 21 statements querying self-reported knowledge, attitudes and practices developed during training and hospital internship. The 21 statements cover five dimensions: 1 ) "openness in communication with the patient (FCP)", with eight statements (FCP1 to FCP8); 2) "Proactive attitude to avoid safety risks (AP)", with four statements (AP1 to AP4); 3) "Awareness of error (AWE)", with three statements (AWE1 to AWE3); 4) "Understanding of human factors (CFH)", with 
four statements (CFH1 to CFH4); and 5) "System complexity and interrelationship (CS)", with two statements (CS1 and CS2). All of them were assessed on a five-point Likert scale: (1) strongly disagree; (2) disagree; (3) neither agree nor disagree; (4) agree; and (5) strongly agree ${ }^{(5,21)}$. Each dimension is evaluated by the average score of statements, scores equal to or higher than four points standing for full acquisition by student of safety contents regarding the competence described in that dimension ${ }^{(5,21)}$.

The validation process of the original instrument was carried out with 786 students in Nursing and Medical courses at eight universities in Chile, Colombia, El Salvador, Guatemala, and Spain. The reliability index (Cronbach's alpha) calculated for the five dimensions of the LSPSQ was higher than 0.7, which indicates good instrument reliability. The results of the multiple linear regression analyses indicated good adjustments of the model (adjustment index: 0.9), and the item-total correlations were greater than 0.3 in all cases. In the analysis of convergent-discriminant validity, all standardized charges were considered significant for the respective factor and greater than 0.6, which demonstrated a good fit of the model (goodness of fit index (GFI): 0.90; adjusted GFI: 0.90$)^{(5)}$. The instrument title in its original version is in English while its statements and dimensions are in Spanish. LSPSQ's main author requested that the original name of the questionnaire be kept in English for both the Spanish and our Portuguese version.

In our study, cross-cultural adaptation of LSPSQ comprised six stages (Figure 1): forward translation; synthesis; back-translation; evaluation by an expert committee; pre-test in a sample of nursing and medical students; and reporting to the original authors ${ }^{(17)}$.

Stage I was carried out by two independent translators, both being bilingual, Brazilian, with proficiency in the Spanish language. Translator 1 had a first degree in nursing, was a university lecturer and was aware of the research objective. Translator 2 had no degree in health sciences and was unaware of the research objective. Both translators were instructed not to consult the scientific articles published on the original LSPSQ questionnaire ${ }^{(17)}$.

At stage II, the two forward translations (T1 and T2) were analyzed and consolidated into a single version by the researchers, thus obtaining version T12. The synthesis of the translations made it possible to ascertain whether there were divergences and discrepancies in the choice of terms and words by the two translators. Version T12 was submitted to analysis by a third translator, referred to in this study as an "observer". He is a university professor with a PhD in the field of applied linguistics, whose mother tongue is Spanish. His analysis was meant to ensure linguistic and cultural adequacy of the translated instrument ${ }^{(17)}$.

At stage III, the instrument in Brazilian Portuguese (version T12) was translated back into Spanish by two other independent bilingual translators ( $R 1$ and R2), university professors in the field of applied linguistics with $\mathrm{PhD}$ degrees in translation studies, the first being a Brazilian speaker and the second one a Spanish speaker. The translators did not have access to the documents or to the original instrument ${ }^{(17,22)}$.

At stage IV, the experts assessed whether the translation of labels for dimensions and their composing statements of the LSPSQ instrument was consistent with the original version, based on the analysis of semantic, idiomatic, cultural, conceptual and item equivalences ${ }^{(17-19)}$. Semantic equivalence refers to equivalence in meaning (grammar and vocabulary); idiomatic equivalence to idiomatic and colloquial expressions; cultural or experiential equivalence refers to equivalence in terms of cultural context or lived experience; conceptual equivalence pertains to the concepts explored and is related to whether an item coheres with whatever it seeks to measure ${ }^{(17,19)}$. Finally, item equivalence implicates analyzing and evaluating pertinence and relevance of the instrument's items to the new context to which it is being adapted ${ }^{(18)}$.

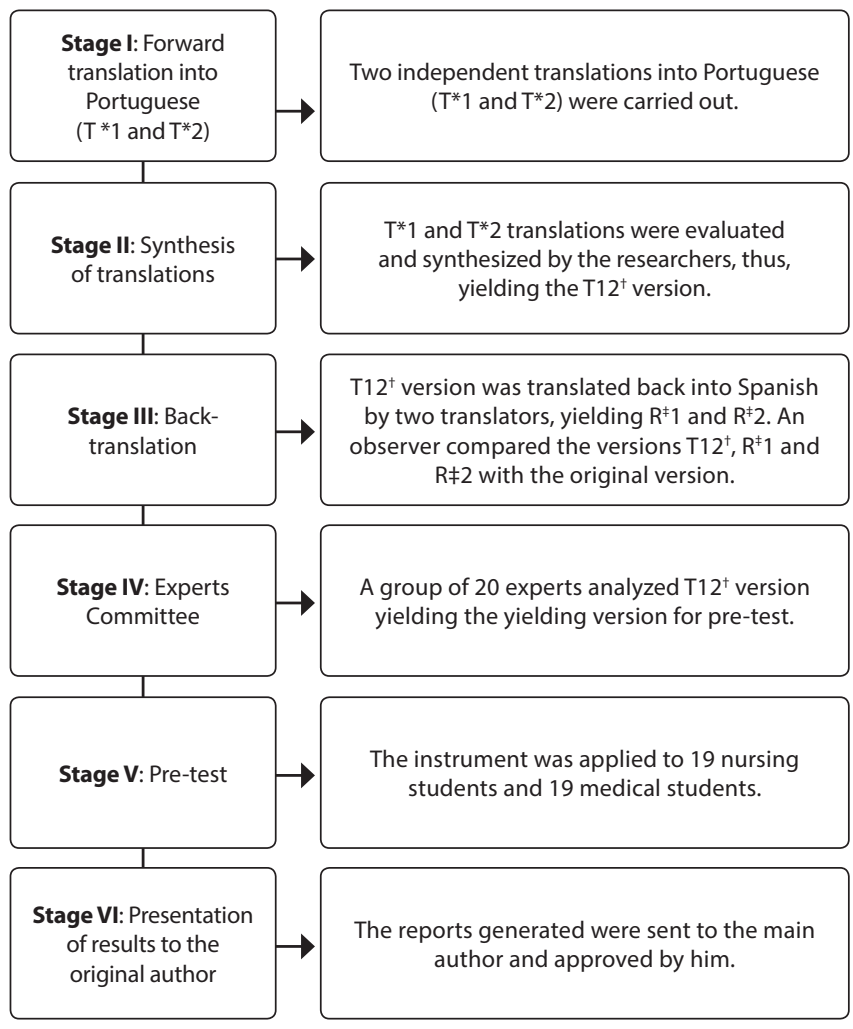

Note: ${ }^{*} T$ - Forward Translation; ${ }^{\dagger} T 12$ - Synthesis; ${ }^{*} R$ - Back translation.

Figure 1 - Methodological path of the cross-cultural adaptation of the Latino Students Patient Safety Questionnaire

Equivalence categories described above were assessed using four options: 1 - non-equivalent item/"requires complete backtranslation"; 2 - item needs major revision to be equivalent/"requires partial translation with many adjustments"; 3 - equivalent item, but requires minor adjustments/"requires partial retranslation with minor adjustments"; and 4 - fully equivalent item/"does not require retranslation at all". Whenever partial or complete retranslation was chosen, participants were requested to state suggestions for their improvement ${ }^{(23)}$.

At stage $V$, the version of the instrument obtained after expert committee assessment was tested with undergraduate students in nursing and medicine. At this stage, students were asked to answer a questionnaire querying for sociodemographic data (gender, age, city/state) and education (course being attending, semester in progress, and university; number of beds in hospital where internship was being or had been carried out, internship field, available direct supervision in the field of practice; other healthcare degree obtained; current engagement as health service worker; reporting whether patient safety had been or was frequently addressed and contextualized by teachers and 
internship supervisors throughout their course). Finally, the reports relevant to all stages were sent to the original author of the instrument (Stage VI) ${ }^{(17)}$.

\section{Analysis of results and statistics}

Content analysis carried out by experts took place through the web platform e-Surv. For validation of expert assessment, the content validity index (CVI) was computed based on the number of responses for fully equivalent item /"does not require translation", divided by the number of participants. Scores $\geq 90 \%$ were considered an acceptable rate of agreement between the experts ${ }^{(23)}$. Statements with scores lower than $90 \%$ were rewritten according to suggestions by the experts. In a spreadsheet editor, the researchers compiled the suggestions pointed out for each item that did not reach the minimum percentage, which allowed for easy examination of the most frequent remarks and suggestions and subsequent reformulation of the items.

At the pre-test stage, students assessed whether the content of each item in the translated version was easy to understand, using three answer options: "no", "in part", and "yes", with the options "no" and "in part" requesting participants to account for their assessment and provide suggestions for improvement. Agreement between the answers was analyzed by computing the number of "yes" answers obtained for an item, divided by the total number of participants. Items with scores below 90\% were rewritten based on the students' suggestions ${ }^{(23)}$. The data, exported from the e-Surv web platform, were organized on a spreadsheet. All descriptive analyses of the data referring to participant sociodemographic data were also carried out on the e-Surv web platform.

\section{RESULTS}

The LSPSQ instrument was culturally adapted to Brazilian Portuguese. The two versions of the LSPSQ forward translation (T1 and T2) showed analogous choices, requiring adjustments regarding clinical terms. The translation performed by $\mathrm{T} 1$ showed greater equivalence in health specific terms when compared to T2. A T12 synthesis version was obtained after two rounds of discussion among translators, researchers, and the observer.

For back-translation, the two independent translations were compared to the original version by the observer, and both were considered similar to the original version in terms of content and context, presenting only a few distinct terms between the versions, with no difference in meaning.

As for the 20 participants in the expert committee, $80 \%(n=16)$ were female, all declared that they had reading proficiency in Spanish and that they had already participated in an expert committee for translation and cross-cultural adaptation of instruments. Of the 10 linguists, $40 \%(n=4)$ were pursuing a doctoral degree; $20 \%(n=2)$, a master's degree; 30\% ( $n=3)$ had a doctoral degree; and 10\% ( $=1$ ) had been engaged in postdoctoral research. Regarding the 10 healthcare professionals, all were nurses, four (40\%) had published articles on patient safety, four (40\%) had written works on the topic, among which one (10\%) had published a diploma course final report; one (10\%) had written a diploma and a master's degree thesis; and two (20\%) had written a diploma, master's thesis , and a PhD dissertation. Five of these participants (50\%) taught course on patient safety or had already been engaged in training on the topic; two (20\%) had worked in patient safety centers in a healthcare institution. It should be noted that $50 \%(n=5)$ of the healthcare professionals had developed studies on translation, cross-cultural adaptation and validation of instruments in the healthcare area.

In the first round of discussion, 26 items, 5 dimensions labels and 21 statements were inputted on the e-Surv web platform for evaluation of the translation by the expert committee, with 21 $(81 \%)$ items from LSPSQ having an agreement index lower than $90 \%$ for equivalence analysis, requiring language adjustment. Four statements (19\%) - FCP3, AWE2, AWE3 and CFH3 - required lexical and grammatical corrections. Cultural equivalence and item equivalence did not apply to the statements FCP1, FCP4 to FCP6, CFH1, and CFH2. Regarding the eight (31\%) statements included in dimension "Openness in communication with the patient (FCP)", all showed an agreement below 90\%, requiring language and cultural adjustments on the topic "patient safety". All four (15.4\%) statements of dimension "Proactive attitude to avoid safety risks (AP)" underwent language corrections and standardization of terms. The three (11.5\%) statements of dimension "Awareness of error (AWE)" required language adjustment and standardization of terminology. Four (15.4\%) statements of dimension "Understanding of human factor (CFH)" were rewritten to adjust to the Portuguese language. Finally, the two (7.7\%) statements of dimension "System complexity interrelationship (CS)" required adaptation of terms to meet cultural equivalence.

For statements FCP1, FCP4, FCP5, FCP6, AP1, AP2, AP4, AWE1, AWE2, AWE3, CFH3, CS1, and CS2, it was necessary to standardize expressions in order to provide a better understanding by the target audience. The expression "informar corretamente" (to adequately report) was replaced by "a forma correta de relatar" (the correct way to report), as it had originally not reach agreement with regard to semantic and conceptual equivalence. The expressions "ao longo da minha formação" (throughout my education and training), "durante meu período de estágio" (during my practices) and "ao longo do período dos meus estudos" (throughout my studies) were rewritten replaced, respectively, as "durante minha formação" (during my education and training), "durante meu estágio" (during my internship), and "durante meus estudos" (during my studies), to meet idiomatic equivalence.

As for the statement FCP6, it was necessary to replace the verb "experimentar" (to try) by the verb "vivenciar" (to experience/to go through the experience) to meet cultural equivalence. In statement FCP7, for the plural form ("Hemos aprendido") the expert committee opted for the first person singular "Eu aprendi" (I have learned), making this choice extensive to the entire instrument, since the statements in the original version were all written in first person singular.

In statement FCP8, there was a need to standardize the expressions "caso ocorresse" (if this were to happen) and "se repetisse" (if this would recur). This was based on the need for ensuring a clearer understanding by students, avoiding redundancy and to meet idiomatic and semantic equivalence. In statement AP1, the expression "me explicaram" (I was explained) was replaced by "recebi explicações" (I was given explanations) so as to meet idiomatic equivalence. 
Regarding the statements $\mathrm{AP} 2, \mathrm{AP} 3, \mathrm{AP} 4, \mathrm{CFH} 1, \mathrm{CFH} 2, \mathrm{CS} 1$, and CS2, rewriting was done for grammatical expressions and verbs, so as to meet semantic, conceptual, idiomatic and item equivalences. Rewritings included "volte acontecer no futuro" (happens again in the future) as "não ocorra novamente" (does not happen again); "mais fáceis" (easier) as "mais comuns" (more common); "formas de como" (how to do forms) as "formas" (forms); "para fazer mais segura a assistência à saúde" (to make healthcare assistance safer) as "para tornar a assistência à saúde mais segura" (to make health assistance safer);"onde" (where) by "em que" (in which); "protocolos assistenciais" (assistance protocols) as "protocolos" (protocols); "comprovei" (I noticed) as "observei"(I observed); "impossível de evitar" (impossible to avoid) as "impossível evitar" (impossible avoiding) and "protocolos que se aplicam" (applicable protocols) by "protocolos aplicados" (applied protocols). In statement CFH2, there was a suggestion to culturally adapt the term "assistência médica" (medical assistance) as "assistência à saúde" (healthcare assistance).

Regarding content validity, the statements FCP1, FCP2, FCP4, FCP5, FCP6, FCP7, FCP8, AP1 to AP4, AWE1, CFH1, CFH2, CS1, $\mathrm{CS} 2$, and the dimension "Proactive attitude to avoid safety risks (AP) were rewritten to meet semantic, idiomatic, and conceptual equivalences. In addition, the statements FCP1, FCP4 to FCP6, CFH1, and $\mathrm{CFH} 2$ were adapted for cultural and item equivalence. Items FCP3, AWE2, AWE3, and CFH3 showed the need for grammatical improvement, such as insertion of commas and backslashes.

Stage V (pre-test) recruited 19 (50\%) students of the nursing course, 12 (32\%) of them in their 8 th course semester and 7 (18\%) in their 9th. Out of the 19 (50\%) medical students, 11 (29\%) were in their 10th semester; $6(15.8 \%)$ in their 12 th; $1(2.6 \%)$ in his $9^{\text {th }}$ semester; and 1 (2.6\%) in his 11 th semester. At the time of data collection, 20 (52.5\%) were interns in hospitals; 12 (31.5\%) in Primary Health Care (PHC) units; and 6 (16\%) in other supervised internship fields. Regarding supervision of their internship, 29 (76.3\%) reported being under direct supervision, 8 (21\%) reported part supervision; and only $1(2.7 \%)$ reported no supervision at all.

Most of the students, 27 (71\%), were female, with an average age of 25 years. As for their education, eight (21\%) students had taken healthcare courses (technical courses and university ones). When asked about how the topic of patient safety was discussed in classes and internships, 19 (50\%) stated that the topic was "regularly" addressed by their instructors, 16 (42\%) said that the topic was addressed "a few times", and 3 (8\%) said that "it was not addressed" at all. At this stage, LSPSQ was approved by students. Of the 21 statements in the pre-final version, only 3 (FCP1, FCP2, FCP8) of dimension "Openness in communication (FCP)", had an agreement below $90 \%$, requiring revision regarding statement comprehension. In statement FCP1, the expression " $a$ forma correta de relatar" (the adequate form to report) was rewritten as "a forma correta de fornecer informações" (the adequate way to provide information); and, in the statement FCP2, the expression "avaliar os riscos à segurança do paciente" (to assess the risks to patient safety) was rewritten as "avaliar os riscos que podem comprometer a segurança do paciente" (to assess the risks that can affect patient safety). Statement FCP8 showed agreement below $90 \%$, but no suggestions to rewrite it were provided. The students stated that the topic "cultura de segurança" (non-punitive culture) was not addressed in their undergraduate courses and were not familiar with it; therefore, they were unable to provide suggestions.
Researchers chose to keep statement FCP8 as it was since the term "non-punitive culture" refers to an established concept in the field of patient safety. The content of the final adapted version of LSPSQ is shown in Chart 1.

Chart 1 - Cross-culturally adapted final version of the Latino Students Patient Safety Questionnaire for Brazilian Portuguese, Divinópolis. Minas Gerais, Brazil, 2017

\begin{tabular}{|c|c|c|}
\hline Dimensions & Code & Items \\
\hline \multirow{8}{*}{$\begin{array}{l}\text { Franquezana } \\
\text { comunicação } \\
\text { com paciente } \\
\text { (FCP) }\end{array}$} & FCP1 & $\begin{array}{l}\text { Aprendi a forma correta de fornecer informações } \\
\text { aos pacientes que sofreram algum dano ou lesão } \\
\text { por causa de um erro. }\end{array}$ \\
\hline & FCP2 & $\begin{array}{l}\text { Durante o estágio, aprendi a avaliar os riscos que } \\
\text { podem comprometer a segurança do paciente. }\end{array}$ \\
\hline & FCP3 & $\begin{array}{l}\text { No estágio, aprendi o que devo fazer se eu } \\
\text { cometer um erro. }\end{array}$ \\
\hline & FCP4 & $\begin{array}{l}\text { Durante o estágio, tive a oportunidade de discutir } \\
\text { com meus tutores ou preceptores qualquer } \\
\text { condição de insegurança que eu pudesse ter } \\
\text { observado. }\end{array}$ \\
\hline & FCP5 & $\begin{array}{l}\text { Durante minha formação, adquiri competências } \\
\text { sobre como relatar corretamente um erro aos } \\
\text { meus colegas e aos meus superiores. }\end{array}$ \\
\hline & FCP6 & $\begin{array}{l}\text { Durante minha formação, fui trabalhando } \\
\text { os sentimentos que posso vir a vivenciar se eu } \\
\text { cometer um erro. }\end{array}$ \\
\hline & FCP7 & $\begin{array}{l}\text { Aprendi como me comunicar melhor com os } \\
\text { pacientes para evitar erros de medicação. }\end{array}$ \\
\hline & FCP8 & $\begin{array}{l}\text { No hospital onde fiz meu estágio, promovia- } \\
\text { se uma cultura não punitiva, para que, caso } \\
\text { ocorresse um erro, soubéssemos como evitar que } \\
\text { ele se repetisse. }\end{array}$ \\
\hline \multirow{4}{*}{$\begin{array}{l}\text { Atitude } \\
\text { proativa para } \\
\text { evitar risco à } \\
\text { segurança (AP) }\end{array}$} & AP1 & $\begin{array}{l}\text { Durante meus estudos, recebi explicações } \\
\text { sobre o que devo fazer para evitar os erros mais } \\
\text { frequentes e garantir a segurança do paciente. }\end{array}$ \\
\hline & AP2 & $\begin{array}{l}\text { Durante o estágio, aprendi que, quando acontece } \\
\text { um erro, devem ser tomadas medidas para que } \\
\text { não ocorra novamente. }\end{array}$ \\
\hline & AP3 & $\begin{array}{l}\text { Os professores discutem em sala de aula os erros } \\
\text { mais comuns de serem cometidos e nos apontam } \\
\text { formas de evitá-los. }\end{array}$ \\
\hline & AP4 & $\begin{array}{l}\text { Durante minha formação, os professores nos } \\
\text { explicaram os objetivos eas prioridades para } \\
\text { tornar a assistência à saúde mais segura. }\end{array}$ \\
\hline \multirow{3}{*}{$\begin{array}{l}\text { Consciência do } \\
\text { erro (CE) }\end{array}$} & CE1 & $\begin{array}{l}\text { Durante meu estágio, pelo menos em uma } \\
\text { ocasião, fiz algo que não era seguro para o } \\
\text { paciente. }\end{array}$ \\
\hline & CE2 & $\begin{array}{l}\text { Durante meu estágio, vi um colega fazer algo que } \\
\text { não era seguro para o paciente. }\end{array}$ \\
\hline & CE3 & $\begin{array}{l}\text { Durante meu estágio, vi profissionais fazerem } \\
\text { algo que não era seguro para o paciente. }\end{array}$ \\
\hline \multirow{4}{*}{$\begin{array}{l}\text { Compreensão } \\
\text { do fator } \\
\text { humano (CFH) }\end{array}$} & $\mathrm{CFH} 1$ & $\begin{array}{l}\text { Nos serviços de saúde, em que realizei meus } \\
\text { estágios, me explicaram as normas de segurança } \\
\text { adotadas para os pacientes. }\end{array}$ \\
\hline & $\mathrm{CFH} 2$ & $\begin{array}{l}\text { Os professores enfatizaram a importância de } \\
\text { seguir os protocolos para uma melhor assistência } \\
\text { à saúde. }\end{array}$ \\
\hline & $\mathrm{CFH} 3$ & $\begin{array}{l}\text { Durante o estágio, foi enfatizada a importância, } \\
\text { para a segurança do paciente, de se fazer uso } \\
\text { adequado dos recursos terapêuticos. }\end{array}$ \\
\hline & $\mathrm{CFH} 4$ & $\begin{array}{l}\text { Os professores enfatizaram a importância de se } \\
\text { lavar as mãos. }\end{array}$ \\
\hline
\end{tabular}

To be continued 
Chart 1 (concluded)

\begin{tabular}{|l|l|l|}
\hline Dimensions & Code & Items \\
\hline $\begin{array}{l}\text { A complexidade } \\
\text { dos sistemase } \\
\text { sua inter- } \\
\text { relação }(\mathrm{CS})\end{array}$ & CS1 & $\begin{array}{l}\text { No estágio, observei que é impossível evitar a } \\
\text { maioria dos erros clínicos. }\end{array}$ \\
\cline { 2 - 3 } & CS2 & $\begin{array}{l}\text { Durante meu estágio, observei que os protocolos } \\
\text { aplicados para garantir a segurança dos } \\
\text { pacientes estão desatualizados (obsoletos). }\end{array}$ \\
\hline
\end{tabular}

Note: FCP - statements of the dimension "Franqueza na comunicação com paciente" (Openness in communication); AP-statements of the dimension "Atitude proativa para evitar risco à segurança" (Proactive attitude to avoid safety risks); AWE - Statements of the "Consciência do erro (CE)" (Awareness of error) dimension; CFH-Statements of the dimension "Compreensão do fator humano" (understanding of human factor); CS - Statements of the dimension "A complexidade dos sistemas e sua inter-relação" (system complexity and interrelationship)".

\section{DISCUSSION}

The LSPSQ assesses a set of skills acquired during the training of Nursing and Medical students. The instrument items refer to both students" attitudes and knowledge developed during the clinical hospital experience; they also refer to their perception of errors, occurrence of adverse events, effective communication, interdisciplinary relationship, proactive attitudes, and understanding of the human factor ${ }^{(5,21)}$. Given its scope, this questionnaire can be considered more complete than other similar international instruments ${ }^{(13-16)}$, such as the Medical Student Patient Safety Questionnaire (Year 1$)^{(14)}$, which mainly assesses attitudes of medical students.

Using instruments that make it possible to analyze and discuss gaps in the academic training process on these topics is relevant both to direct curricular planning and to alert the student about the importance of acquiring knowledge and attitudes for safe performance in clinical practice ${ }^{(5,10)}$.

Thus, since instruments validated for this purpose have not yet been identified in Brazil, translation and cross-cultural adaptation of the LSPSQ is very welcome. This is particularly so because the instrument allows to assess whether undergraduate Nursing or Medical students meet their training goals regarding patient safety and, thus, impacts the reduction of barriers to the inclusion of this topic in curricula. The evaluated items address essential skills in the training process of prospective professionals, which are in line with the guidelines provided by the WHO in the Multiprofessional Patient Safety Curriculum Guide (2).

To translate and cross-culturally adapt the instrument, technical, linguistic, and semantic aspects must be considered. In this study, a rigorous process of cross-cultural adaptation of the LSPSQ to the Portuguese language was carried out, meeting all methodological requirements ${ }^{(17-19,22)}$. The evaluation phase of the synthesis version (T12) of the LSPSQ by the expert committee enhanced the instrument adaptation, as the accuracy and methodological expertise of the members enabled the formulation of a pre-final version closer to the original. This was possible due to the interdisciplinary nature of the committee, which allowed an in-depth identification and assessment of all problems in the adapted version and enabled sharing viewpoints between the areas of expertise.

Among the relevant results of content validation, the rewriting requested in statements FCP1 and FCP5 are worth noting, in which the term "informar corretamente" (to adequately report) was rewritten as "a forma correta de relatar" (the adequate way to report), in order to express the errors for colleagues and superiors of the student regarding patients. Error notification must be performed by any professional who acts directly or indirectly in patient care. However, ineffective communication can directly result in damage to the patient or in their death ${ }^{(24)}$.

Communication between healthcare professionals takes place in different places and situations. Therefore, it is important to standardize and systematize it at all hierarchical and organizational levels of an institution ${ }^{(25)}$. Studies indicate that failures in the work process and ineffective communication between health professionals have been some of the main factors that converge to errors and adverse events, thus affecting the quality of care provided $^{(25-26)}$.

In statement FCP4, it was necessary to replace the verb "comentar" (comment) by the verb "discutir" (discuss), as it better represents the commitment by teachers or internship preceptors and students, since "comment" denotes non-obligation to discuss and teach something relevant to the training process. In this context, the teacher or internship preceptor has the role of being a transforming agent of the teaching-learning process. They need to assist students to understand the care process, allowing freedom of expression and providing conditions for change ${ }^{(10)}$.

Further rewriting in statement FCP4 included replacing the word "supervisor" (supervisor) by the word "preceptor do estágio" (internship preceptor). The word "supervisor" refers to a professional who occupies an administrative position, managing a sector, and the term mostly used in Brazilian universities is "tutor" or "preceptor", referring to the person overseeing the internship. A preceptor is understood as a professional of the healthcare network of extreme importance to introduce students and recent graduates to professional and clinical practice. His duty is to assist students in developing their clinical skills and assess them during their training period. Also, the role of a tutor is to guide, facilitate the student's teaching-learning process in order to guide their professional practice ${ }^{(27)}$.

It should be noted that the aim of rewriting was to ensure the cross-cultural adaptation of the LSPSQ instrument to the Brazilian context, without losing its originality. Therefore, for the statement $\mathrm{CFH} 1$, it was also suggested to rewrite the expression "de saúde" (healthcare) as "serviços de saúde" (healthcare services), as it better represents the places of supervised internship. Still regarding this statement, the experts suggested grammatical adequacy of the term "normas de segurança" (safety standards) in relation to students in the internship field, and not for the patient. The instrument's focus is to analyze the knowledge and attitude about patient safety (specific skills) acquired by the student during the supervised internships ${ }^{(5,21)}$.

Comments by the students about statement FCP8 are worth highlighting, regarding their lack of familiarity with the meaning of the term "non-punitive culture" and, therefore, their difficulty in providing suggestions on that item. The researchers chose to keep the statement, as it is one of the areas covered in the curriculum ${ }^{(2)}$ for academic training of nursing and medical students regarding patient safety. The absence of the theme during formation makes it difficult to understand the non-punitive culture, meaning that the "punitive culture" prevails as a way to deal with failures and errors in health care, based on a personal approach, in which the individuals are held accountable and punished due to incidents ${ }^{(2)}$. 
Still in the pre-test phase, when students answered one of the items of characterization of the academic profile, which questions whether the theme is frequently addressed and contextualized by teachers and internship preceptors throughout the course, they stated that the theme, in general, is not discussed. The introduction of the theme in universities has been prioritized in post-graduation education ${ }^{(8)}$. In addition, learning occurs with few possibilities for interdisciplinary exchange, demonstrating the growing need to insert the topic in the curricula for professional training ${ }^{(4,7,10,21)}$.

A Brazilian study that evaluated the pedagogical projects of Nursing and Medicine undergraduate courses identified that the teaching of patient safety lacks depth and conceptual breadth ${ }^{(8)}$. Therefore, the pedagogical models adopted at universities with regard to clinical approaches, discussion of concepts, demonstration of best practices, and skills in the field of error (human fallibility) and patient safety must be improved ${ }^{(1,4,8,10)}$.

Considering this context, it is expected that the widespread use of LSPSQ in Brazil will contribute to the strengthening of the theme in teaching, research, and extension in universities, instigating important reflections on the abilities that need to be developed during academic training, in order to promote safer health care.

\section{Study limitations}

The limitations of the study were: R1 translator was a Brazilian national and not from a Spanish-speaking country, as proposed by the methodological framework ${ }^{(17)}$, since it was difficult for researchers to have access to a professional with this profile; students who participated in the pre-test were selected at a single educational institution; and there were no medical professionals in the composition of the group of specialists.

\section{Contributions to the sectors of Nursing, Health and Public Policy}

The LSPSQ is considered to be an useful and adequate tool to provide educational institutions, managers, and teachers with parameters for the development of specific skills in the area of patient safety. In addition, it can contribute to the students' reflection process, helping them to change attitudes (behaviors), evaluate the work process, manage errors, and build a positive non-punitive culture during their training.

\section{CONCLUSIONS}

The instrument has content validity to assess the knowledge and attitudes regarding patient safety of Nursing and Medicine students in hospital practice activities. It is worth highlighting that there are no studies that apply validated instruments to assess the knowledge of nursing and medical students about patient safety, and, thus, adopt indexes for measuring quality.

Further studies are recommended in order to develop the instrument's psychometric validity process with the target audience. In addition, new studies are suggested to expand the applicability of the instrument to other students in the health field, given the cross-sectional nature of the theme, training, and health professionals. Therefore, the instrument may favor the teaching-learning process on patient safety, identifying gaps to be worked on in the educational institution, so that the future health professional provides safer care to the patient.

\section{REFERENCES}

1. Mansour MJ, Al Shadafan SF, Abu-Sneineh FT, Al Amer MM. Integrating patient safety education in the undergraduate nursing curriculum: a discussion paper. Open Nurs J. 2018;29(12):125-32. doi: 10.2174/1874434601812010125

2. World Health Organization. WHO patient safety curriculum guide: multi-professional edition. Genebra: WHO [Internet]. 2011 [cited 2020 May 23]. Available from: http://apps.who.int/iris/bitstream/10665/44641/1/9789241501958_eng.pdf?ua

3. Ministério da Saúde (BR). Portaria n. 529 de 1º de abril de 2013: institui o Programa Nacional de Segurança do Paciente (PNSP) [Internet]. Brasília (DF); 2013[cited 23 May 2020]. Available from: http://bvsms.saude.gov.br/bvs/saudelegis/gm/2013/prt0529_01_04_2013.html

4. Ginsburg LR, Dhingra-Kumar N, Donaldson L. What stage are low-income and middle-income countries (LMICs) at with patient safety curriculum implementation and what are the barriers to implementation? a two-stage cross-sectional study. BMJ Open. 2017;7:e016110. doi: 10.1136/ bmjopen-2017-016110

5. Mira JJ, Navarro IM, Guilabert M, Poblete R, Franco AL, Jiménez P, et al. A Spanish-language patient safety questionnaire to measure medical and nursing students' attitudes and knowledge. Rev Panam Salud Publica[Internet]. 2015 [cited 2020 May 23];38(2):110-9. Available from: https://scielosp.org/article/rpsp/2015.v38n2/110-119/

6. Yoshikawa JM, Sousa BEC, Peterlini MAS, Kusahara DM, Pedreira MLG, Avelar AFM. Comprehension of undergraduate students in nursing and medicine on patient safety. Acta Paul. Enferm. 2013;6(1):21-29. doi: 10.1590/S0103-21002013000100005

7. Bohomol E, Cunha ICKO. Teaching patient safety in the medical undergraduate program at the Universidade Federal de São Paulo. Einstein. 2015;13(1):7-13. doi: 10.1590/S1679-45082015AO3089

8. Bohomol E, Freitas MAO, Cunha ICKO. Patient safety teaching in undergraduate health programs: reflections on knowledge and practice. Interface. 2016;20(58):727-41. doi: 10.1590/1807-57622015.0699

9. Ilha P, Radünz V, Tourinho FSV, Marinho MM. Patient safety from the perspective of nursing students. Cogitare Enferm[Internet]. 2016 [cited 2020 May 23];21(n.esp):01-10. Available from: https://revistas.ufpr.br/cogitare/article/view/43620/pdf_1

10. Cauduro GMR, Magnago TSBS, Andolhe R, Lanes TC, Dal Ongaro J. Patient safety in the understanding of health care students. Rev Gaúch Enferm. 2017;38(2):e64818. doi:10.1590/1983-1447.2017.02.64818 
11. Bim LL, Bim FL, Silva AMB, Sousa AFL, Hermann PRS, Andrade D, Hass VJ. Theoretical-practical acquisition of topics relevant to patient safety: dilemmas in the training of nurses. Esc Anna Nery.2017;21(4):e20170127. doi: 10.1590/2177-9465-ean-2017-0127

12. Ginsburg LR, Tregunno D, Norton PG, Smme S, Vries I, Sebok SS, et al. Development and testing of an objective structured clinical exam (OSCE) to assess socio-cultural dimensions of patient safety competency. BMJ Qual Saf. 2015;24(3):188-94. doi: 10.1136/bmjqs-2014-003277

13. Madigosky WS, Headrick La, Nelson K, Cox KR, Anderson T. Changing and sustaining medical student's Knowledge skills, and attitudes about patient safety and medical fallibility. Acad Med. 2006:81(1):94-101. doi: 10.1097/00001888-200601000-00022

14. Flin R, Patey R, Jackson J, Mearns K, Dissanayaka U. Year 1 medical undergraduates' knowledge of and attitudes to medical error. Med Educ. 2009:43(12):1147-55. doi: 10.1111/j.1365-2923.2009.03499.x

15. Ginsburg L, Castel E, Tregunno D, Norton PG. The H-PEPSS: an instrument to measure health professionals' perceptions of patient safety competence at entry into practice. BMJ Qual Saf. 2012:21(8):676-84. doi: 10.1136/bmjqs-2011-000601

16. Lee $\mathrm{N}-\mathrm{J}$, Jang H, Park S-Y. Patient safety education and baccalaureate nursing students' patient safety competency: a cross-sectional study. Nurs Health Sci. 2016:18(2):163-71. doi: 10.1111/nhs.12237

17. Beaton DE, Bombardier C, Guillemin F, Ferraz MB. Recommendations for the cross-cultural adaptation of the DASH \& QuickDASH. Outcome Measures, Institute for Work \& Health [Internet]. 2007[cited 2020 Apr 01];1-45. Available from: http://www.dash.iwh.on.ca/sites/dash/files/ downloads/cross_cultural_adaptation_2007.pdf

18. Herdman M, Fox-Rushby J, Badia X. A model of equivalence in the cultural adaptation of HRQoL instruments: the universalist approach. Qual Life Res. 1998;7(4):323-35. doi: 10.1023/a:102498593053

19. Guillemin F, Bombardier C, Beaton D. Cross-cultural adaptation of health-related quality of life measures: literature review and proposed guidelines. J Clin Epidemiol. 1993;46(12):1417-32. doi: 10.1016/0895-4356(93)90142-n

20. Grant JS, Davis LL. Seletion and use of content experts for instrument development. Res Nurs Health. 1997:20(3):269-74. doi: 10.1002/ (sici) 1098-240x(199706)20:3<269::aid-nur9>3.0.co;2-g

21. Mira JJ, Guilabert M, Vitaller J, Ignacio E. Formación em seguridade del paciente em las escuelas de medicina y enfermeira em España. Rev Calid Asis. 2016;31(3):141-5. doi:10.1016/j.cali.2015.08.008

22. Epstein J, Santo RM, Guillemin F. A review of guidelines for cross-cultural adaptation of questionnaires could not bring out a consensus. J Clin Epidemiol. 2015;68(4):435-41. doi: 10.1016/j.jclinepi.2014.11.02

23. Souza AC, Alexandre NMC, Guirardello EB. Psychometric properties in instruments evaluation of reliability and validity. Epidemiol Serv Saúde. 2017;26(3):649-59. doi: 10.5123/s1679-49742017000300022

24. Makary MA, Daniel M. Medical error-the third leading cause of death in the US. BMJ. 2016;353:i2139. doi: 10.1136/bmj.i2139

25. Lee JY. Effective communication for patient safety. J Korean Med Assoc. 2015;58(2):100-4. doi: 10.5124/jkma.2015.58.2.100

26. Lawson S, Reid J, Morrow M, Gardiner K. Simulation-based Education and Human Factors Training in Postgraduate Medical Education: a Northern Ireland perspective. Ulster Med J [Internet]. 2018[cited 2020 Apr 01];87(3):163-7. Available from: https://www.ncbi.nlm.nih.gov/ pmc/articles/PMC6169420/

27. Oliveira SF, Cunha AJLA, Trajman A, Teixeira C, Gomes MK, Halfoun V. Perception about the Medical Internship at Federal University of Rio de Janeiro by the Service Preceptors in Primary Health Care: a case study. Rev Bras Educ Méd. 2017;41(2):320-6. doi: 10.1590/1981-52712015v41n2rb20160031 